Check for updates

Cite this: RSC Adv., 2017, 7, 31319

\title{
Transformation behavior of potassium during pyrolysis of biomass
}

\author{
Chen Chen, (D) Zhongyang Luo, Chunjiang Yu, Tao Wang* and Hengli Zhang
}

The present work studied the transformation behavior of $\mathrm{K}$ involving the change of water-insoluble $\mathrm{K}$ and $\mathrm{K}_{2} \mathrm{CO}_{3}$ during biomass pyrolysis. $\mathrm{KCl}$-loaded cellulose samples were used as fuels with the aim to determine the key reactions involved during $\mathrm{K}$ transformation. For comparision, $\mathrm{KCl}$-loaded char samples were used as fuels to eliminate the effect of organics in cellulose on $\mathrm{K}$ transformation. The total amounts of $\mathrm{K}$, and watersoluble $\mathrm{K} \mathrm{Cl}^{-}$, and $\mathrm{CO}_{3}{ }^{2-}$ in the fuels and in the obtained solid residues were quantified. The quantification results indicated that, during the pyrolysis of the $\mathrm{KCl}$-loaded cellulose, the reactions between $\mathrm{KCl}$ and active functional groups which are produced from organic matter in cellulose during pyrolysis lead to a certain amount of water-insoluble $\mathrm{K}$ formed above $300{ }^{\circ} \mathrm{C}$ and the water-insoluble $\mathrm{K}$ was transformed into $\mathrm{K}_{2} \mathrm{CO}_{3}$ above $600^{\circ} \mathrm{C}$. The reactions between $\mathrm{KCl}$ and the organic matter in the cellulose were governed by both the availability of active functional groups produced during cellulose pyrolysis and the amount of $\mathrm{KCl}$. The presence of $\mathrm{O}_{2}$ promoted the generation of $\mathrm{K}_{2} \mathrm{CO}_{3}$.

Received 8th May 2017

Accepted 12th June 2017

DOI: 10.1039/c7ra05162j

rsc.li/rsc-advances as wood, rice straw, and wheat straw are 0.1-2.2 wt\% and 0.02$0.67 \mathrm{wt} \%$, respectively, as reported in the literature..$^{3,8-16}$

The transformation behavior of $\mathrm{K}$ during biomass thermal conversion depends on the temperature which can be divided into two zones, above and below $700{ }^{\circ} \mathrm{C}$. Johansen et al. ${ }^{\mathbf{1 1}}$ and van Lith et al. ${ }^{17}$ found that about $10 \%$ of $\mathrm{K}$ was released below $700{ }^{\circ} \mathrm{C}$, which was generally identified as the result of organic $\mathrm{K}$ decomposition. At temperatures higher than $700{ }^{\circ} \mathrm{C}$, large amounts of $\mathrm{K}$ were released as $\mathrm{KCl}$, since the vapor pressure of this compound significantly increased. ${ }^{3,8,10,18,19}$ On the other hand, $\mathrm{K}_{2} \mathrm{CO}_{3}$ may be generated through organic $\mathrm{K}$ decomposition at high temperature. ${ }^{20}$ At temperatures above $800{ }^{\circ} \mathrm{C}, \mathrm{K}_{2} \mathrm{CO}_{3}$ would be decomposed ${ }^{3,8,18}$ with the release of $\mathrm{K}$ atoms or $\mathrm{KOH} .{ }^{21}$ However, the pathway of the formation of $\mathrm{K}_{2} \mathrm{CO}_{3}$ during biomass thermal conversion remains unclear and thus represents a critical research need.

According to the well-known low-temperature $\mathrm{Cl}$ release mechanism, ${ }^{12,22} \mathrm{KCl}$ reacts with active functional groups on the char matrix to release $\mathrm{HCl}$ according to the following reaction:

$$
\text { Char-COOH(s) }+\mathrm{KCl}(\mathrm{s}) \rightarrow \text { Char-COOK}(\mathrm{s})+\mathrm{HCl}(\mathrm{g})
$$

Notably, this reaction may lead to the formation of $\mathrm{K}$ which is firmly bound to the char matrix. A few researchers ${ }^{22-25}$ have found that the organic matter in biomass influence the transformation behavior of $\mathrm{K}$ during biomass thermal conversion. However, the interactions between the organic matter of biomass and $\mathrm{KCl}$ during biomass thermal conversion have been rarely investigated in detail.

The aim of the present study is to investigate $\mathrm{K}$ transformation mechanisms during biomass pyrolysis involving the generation of $\mathrm{K}$ firmly bound to the char matrix and $\mathrm{K}_{2} \mathrm{CO}_{3}$.
State Key Laboratory of Clean Energy Utilization, Zhejiang University, Hangzhou 310027, China. E-mail: oatgnaw@zju.edu.cn; Fax: +86-571-87951616; Tel: +86-57187952205 
With this aim, KCl-loaded cellulose samples were used as fuels to determine the key reactions involved during $\mathrm{K}$ transformation. The effects of the residence time and the atmosphere on the $\mathrm{K}$ transformation were also studied.

\section{Experimental}

\subsection{Sample preparation}

Microcrystalline cellulose (C104841, particle size: $90 \mu \mathrm{m}$, Aladdin Industries Corporation, Shanghai, China) was used and its properties are shown in Table 1 . The cellulose was first washed with ultrapure water at room temperature to remove water-soluble compounds and subsequently dried at $35^{\circ} \mathrm{C}$ for $5 \mathrm{~h} .{ }^{26}$ The dried cellulose was loaded with $\mathrm{KCl}$ via wet impregnation at varying $\mathrm{K}$ element contents, i.e., $0.3,1.0,2.0$, and $5.0 \mathrm{wt} \%$, to prepare four different samples (MC0.3, MC1, MC2, and MC5, respectively). The impregnation process involved the preparation of a $\mathrm{KCl}$ aqueous solution and a blending of solution with cellulose to prepare a cellulose-water slurry. The slurry was stirred for $24 \mathrm{~h}$ and subsequently dried at $35^{\circ} \mathrm{C}$ for $8 \mathrm{~h}$. The obtained dry solid matter was ground with an agate mortar and sieved to a particle size (lower than $90 \mu \mathrm{m}$ ) to obtain the KCl-loaded cellulose samples for subsequent experiments. The $\mathrm{K}$ contents in the four $\mathrm{KCl}$-loaded cellulose samples were determined three times to ensure reliable K loading results. A water-washed non-KCl-loaded sample (MC0) was also subjected to the impregnation process.

For the sake of comparison, the MC0 sample was pyrolyzed at $600{ }^{\circ} \mathrm{C}$ for $30 \mathrm{~min}$ and subsequently loaded with $\mathrm{KCl}$ to prepare $\mathrm{KCl}$-loaded char samples (CR) as fuels so that the effect of organics in cellulose on $\mathrm{K}$ transformation in the $\mathrm{CR}$ can be neglected. The $\mathrm{K}$ element content was set as $13 \mathrm{wt} \%$ according to the solid yields and the $\mathrm{K}$ contents of the KCl-loaded cellulose samples.

\subsection{Experimental procedures}

Table 2 lists the experimental conditions used in the present study. Pyrolysis was performed in a laboratory-scale tube reactor at temperatures ranging from 200 to $900{ }^{\circ} \mathrm{C}$. The details of the reactor can be found in our previous work. ${ }^{9}$ In a typical pyrolysis experiment, $0.5 \mathrm{~g}$ of KCl-loaded cellulose or char samples were used. The reactor was preheated and purged with $\mathrm{N}_{2}$, and the sample boat was subsequently inserted into the water-cooled chamber of the reactor. When the reactor reached the set temperature, the sample boat was inserted into the hot zone of the reactor for pyrolysis under a $\mathrm{N}_{2}$ flow rate of $1.5 \mathrm{NL} \mathrm{min}^{-1}$. After $30 \mathrm{~min}$ of reaction, the sample was placed again into the water-cooled chamber and cooled to $60{ }^{\circ} \mathrm{C}$ under $\mathrm{N}_{2}$ purge. The sample was subsequently weighed and stored in a dry and cool environment. Additional experiments were conducted to

Table 1 Proximate and ultimate analysis of the cellulose (wt\%, dry base)

\begin{tabular}{lllllllll}
\hline \multicolumn{2}{l}{ Proximate ananlysis } & & \multicolumn{7}{c}{ Ultimate analysis } \\
\cline { 5 - 8 } V & FC & A & & C & H & O & N & S \\
\hline 94.6 & 5.4 & - & 44.0 & 6.3 & 49.7 & - & -
\end{tabular}

Table 2 Experimental conditions

\begin{tabular}{lllll}
\hline $\begin{array}{l}\text { Experimental } \\
\text { condition name }\end{array}$ & Samples & Atmosphere & $\begin{array}{l}\text { Residence } \\
\text { time }(\mathrm{min})\end{array}$ & $\begin{array}{l}\text { Temperature } \\
\left({ }^{\circ} \mathrm{C}\right)\end{array}$ \\
\hline MC0 & MC0 & $\mathrm{N}_{2}$ & 30 & $200-900$ \\
MC0.3 & MC0.3 & $\mathrm{N}_{2}$ & 30 & $200-900$ \\
MC1 & MC1 & $\mathrm{N}_{2}$ & 30 & $200-900$ \\
MC2 & MC2 & $\mathrm{N}_{2}$ & 30 & $200-900$ \\
MC5 & MC5 & $\mathrm{N}_{2}$ & 30 & $200-900$ \\
CR & $\mathrm{CR}$ & $\mathrm{N}_{2}$ & 30 & $200-900$ \\
MC2 60 min & MC2 & $\mathrm{N}_{2}$ & 60 & 400,800 \\
MC2 combustion & MC2 & 2 vol\% $\mathrm{O}_{2}$ & 30 & 400,800 \\
& & in $\mathrm{N}_{2}$ balance & &
\end{tabular}

investigate the influence of the residence time and the atmosphere. The MC2 samples were pyrolyzed for $60 \mathrm{~min}$ and combusted ( 2 vol\% $\mathrm{O}_{2}$ in $\mathrm{N}_{2}$, total flow rate: $1.5 \mathrm{NL} \mathrm{min}^{-1}$ ) for $30 \mathrm{~min}$ at 400 and $800{ }^{\circ} \mathrm{C}$. The concentration of $\mathrm{O}_{2}$ was chosen as $2 \mathrm{vol} \%$ to minimize the temperature overshoot $\left(<15{ }^{\circ} \mathrm{C}\right.$, measured above the samples). The microscopic morphology and the inorganic matter distribution of the solid residue samples obtained after pyrolysis of MC0, MC2, and MC5 were studied by scanning electron microscopy coupled with energy-dispersive spectroscopy (SEM/EDS, HITACHI SU-70).

The amount of $\mathrm{K}$ transformed and released was quantified by weight measurements and chemical analysis. The total concentrations of $\mathrm{K}$ in the samples were quantified through an acid digestion process. In this process, $50 \mathrm{mg}$ of the samples were dissolved by pressurized microwave digestion in a mixture of $9 \mathrm{~mL}$ of $\mathrm{HNO}_{3}$ and $1 \mathrm{~mL}$ of $\mathrm{H}_{2} \mathrm{O}_{2}$ at $180{ }^{\circ} \mathrm{C}$ for $15 \mathrm{~min}$. After the digestion process, the obtained acid solution was diluted for inductively coupled plasma-atomic emission spectrometry (ICPAES, Thermo iCAP6300) analysis to determine the total concentration of $\mathrm{K}$. Three kinds of standard $\mathrm{K}$ solutions (i.e., 1, 5 , and $10 \mathrm{ppm}$ ) were used for ICP-AES analysis. To ensure measurement accuracy, all the samples tested by ICP-AES were diluted to obtain concentrations within 1-10 ppm. Each group of experiments was repeated 3 times, and the standard deviation was lower than $3 \%$ in all cases.

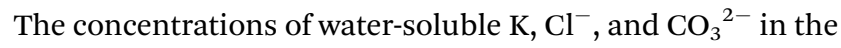
solid residue samples were analyzed by a water extraction process. In a typical water extraction process, $50 \mathrm{mg}$ of the samples were dissolved in ultrapure water with a sample-towater ratio of $0.5 \mathrm{~g} \mathrm{~L}^{-1}$ and stirred for $8 \mathrm{~h}$ at $60{ }^{\circ} \mathrm{C}$. As in the case of the total $\mathrm{K}$ measurements, the concentration of $\mathrm{K}$ in the water solutions was determined by ICP-AES. The concentrations of $\mathrm{Cl}^{-}$and $\mathrm{CO}_{3}{ }^{2-}$ in the water solutions were determined by ion chromatography (IC, DIONEX ICS-2000) with $\mathrm{NaOH}$ solution as the eluent. Each group of experiments was repeated 3 times, and the standard deviation was lower than $3 \%$ in all cases.

\section{Results}

\subsection{Microscopic morphology of the solid residues obtained after pyrolysis}

The solid residues obtained after pyrolysis at $400{ }^{\circ} \mathrm{C}$ were selected to observe the micro-topography of the inorganic 


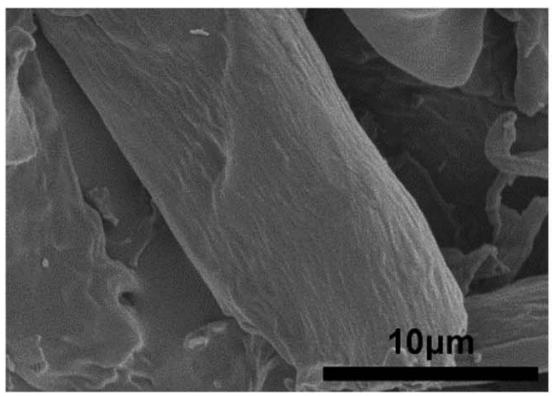

(1)

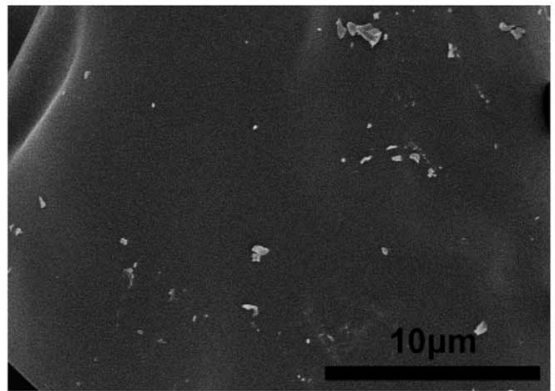

(4)

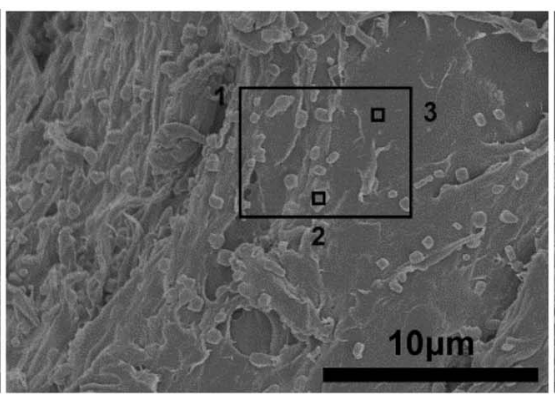

(2)

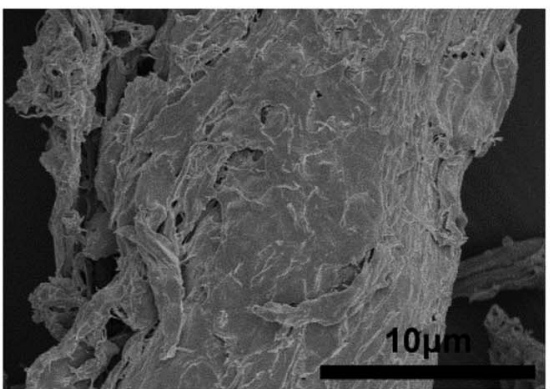

(5)

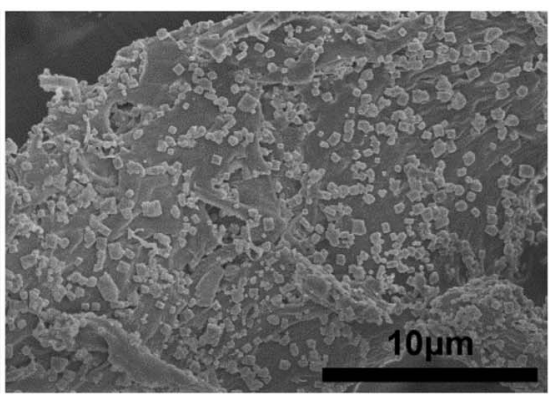

(3)

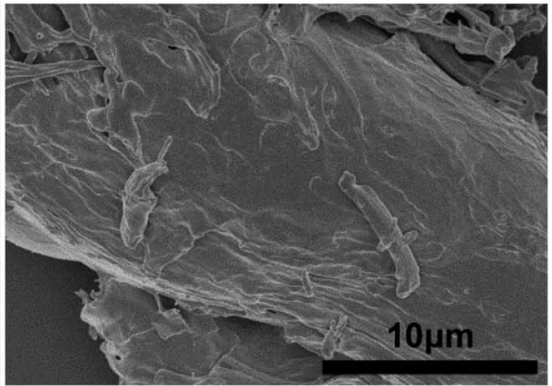

(6)

Fig. 1 SEM images of the solid residues obtained after pyrolysis at 400 and $900{ }^{\circ} \mathrm{C}$ : (1) MCO $400{ }^{\circ} \mathrm{C}$, (2) $\mathrm{MC2} 400{ }^{\circ} \mathrm{C}$, (3) $\mathrm{MC} 5400{ }^{\circ} \mathrm{C}$, (4) $\mathrm{MCO}$ $900{ }^{\circ} \mathrm{C}$, (5) MC2 $900{ }^{\circ} \mathrm{C}$, and (6) MC5 $900{ }^{\circ} \mathrm{C}$.

matter. ${ }^{9}$ With the aim to gain insight into the disappearance of the inorganic matter, samples pyrolyzed at $900{ }^{\circ} \mathrm{C}$ were also selected for these studies. Fig. 1 shows the microscopic morphology of the obtained solid residues after pyrolysis of MC0, MC2, and MC5 at 400 and $900{ }^{\circ} \mathrm{C}$. And Table 3 shows the EDS results at the positions detailed in Fig. 1(2).

As shown in Fig. 1, rough particles $(0.2-1.0 \mu \mathrm{m}$ in size) uniformly distributed over the entire solid residues obtained by pyrolysis of MC2 and MC5 at $400{ }^{\circ} \mathrm{C}$, with the sample derived from MC5 showing the largest number of particles. These rough particles were not found in the solid residues obtained by pyrolysis of MC2 and MC5 at $900{ }^{\circ} \mathrm{C}$, and MC0 at $400{ }^{\circ} \mathrm{C}$ and $900{ }^{\circ} \mathrm{C}$. As detailed in Table 3, higher $\mathrm{K}$ and $\mathrm{Cl}$ concentrations were found at position 2 (Fig. 1(2), point analysis on one particle) as compared to position 3 (point analysis on no particle). Hence, these above results indicated that the rough particles were inorganic particles enriched in $\mathrm{K}$ and $\mathrm{Cl}$. The micro-distribution and particle sizes of the inorganic matter particles obtained herein were similar to those showed on the cell wall of rice straw char. ${ }^{9}$ Thus, $\mathrm{K}$ transformation during pyrolysis of the KCl-loaded cellulose samples through wet impregnation in the present work are comparable with those of natural biomass. In addition, as shown in Fig. 1, the surface of the solid residues obtained after pyrolysis of MC2 and MC5 were

Table 3 EDS results at the positions detailed in Fig. 1(2) (at\%)

\begin{tabular}{lllll}
\hline & $\mathrm{C}$ & $\mathrm{O}$ & $\mathrm{Cl}$ & $\mathrm{K}$ \\
\hline 1 & 84 & 12 & 1.6 & 1.9 \\
2 & 86 & 9 & 2.6 & 2.6 \\
3 & 84 & 14 & 1.0 & 1.4
\end{tabular}

rough and partly broken but that of MC0 was smooth, indicating that reaction between $\mathrm{KCl}$ and cellulose may make surface of char rough.

\subsection{Transformation of $\mathrm{K}$ after pyrolysis}

Table 4 shows the total $\mathrm{K}$, and water-soluble $\mathrm{K}, \mathrm{Cl}^{-}$, and $\mathrm{CO}_{3}{ }^{2-}$ concentrations of the original fuel samples (MC0, MC0.3, MC1, MC2, MC5, and CR) samples. The results show that the concentration of total $\mathrm{K}$ was similar to that of the watersoluble $\mathrm{K}$ and the mole ratio of total $\mathrm{K}$ to water-soluble $\mathrm{Cl}^{-}$ was 1 in all cases. Remarkably, no $\mathrm{CO}_{3}{ }^{2-}$ was found in the water solution, thereby indicating that the totality of the $\mathrm{K}$ and $\mathrm{Cl}^{-}$in the MC0.3, MC1, MC2, MC5, and CR samples remained in the form of $\mathrm{KCl}$ after the wet impregnation process.

The $\mathrm{K}$ retention percentages in the solid phase after pyrolysis of MC0.3, MC1, MC2, MC5 and CR samples for 30 min were calculated using the following equation:

$$
\alpha=\frac{m_{\mathrm{r}} c_{\mathrm{tK}, \mathrm{r}}}{m_{0} c_{\mathrm{tK}, 0}} \times 100 \%
$$

where $m_{0}$ is the weight of the original samples and $m_{\mathrm{r}}$ is the weight of the solid residues obtained after pyrolysis. $c_{\mathrm{tK}, 0}$ and $c_{\mathrm{tK}, \mathrm{r}}$ represent the total $\mathrm{K}$ concentrations in the original samples and in the solid residues (after pyrolysis), respectively.

As shown in Fig. 2, a small fraction of $\mathrm{K}$ was released into the gas phase below $700{ }^{\circ} \mathrm{C}$. The retention of $\mathrm{K}$ by MC0.3, MC1, MC2, and MC5 significantly decreased at pyrolysis temperatures over $600{ }^{\circ} \mathrm{C}$ and reached $43.9-51.4 \%$ at $800{ }^{\circ} \mathrm{C}$. In the case of CR, the $\mathrm{K}$ retention ratio started to decrease above $700{ }^{\circ} \mathrm{C}$. The main difference between the KCl-loaded cellulose fuels samples and CR fuels samples is the former contain organic matter of 
Table 4 Total $\mathrm{K}$ and water-soluble $\mathrm{K}_{1} \mathrm{Cl}^{-}$, and $\mathrm{CO}_{3}{ }^{2-}$ of the $\mathrm{MC0.3}$, MC1, MC2, MC5, and CR samples (wt\%)

\begin{tabular}{|c|c|c|c|c|}
\hline & Total K & $\begin{array}{l}\text { Water-soluble } \\
\mathrm{K}\end{array}$ & $\begin{array}{l}\text { Water-soluble } \\
\mathrm{Cl}^{-}\end{array}$ & $\begin{array}{l}\text { Water-soluble } \\
\mathrm{CO}_{3}{ }^{2-}\end{array}$ \\
\hline MC0 & 0.000 & 0.000 & 0.000 & 0.000 \\
\hline MC0.3 & 0.301 & 0.302 & 0.273 & 0.000 \\
\hline MC1 & 0.999 & 1.000 & 0.913 & 0.000 \\
\hline MC2 & 2.001 & 2.001 & 1.825 & 0.000 \\
\hline MC5 & 5.002 & 5.002 & 4.561 & 0.000 \\
\hline CR & 13.120 & 13.121 & 11.921 & 0.000 \\
\hline
\end{tabular}

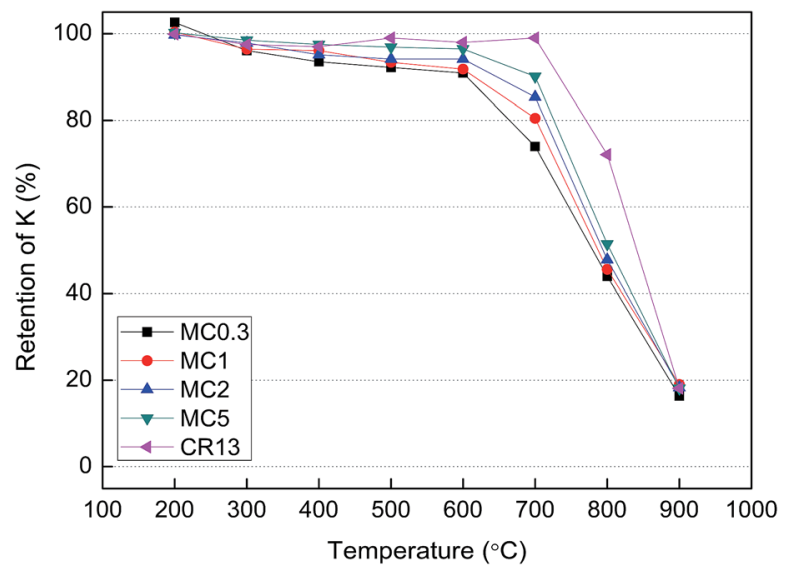

Fig. 2 Percentage of $K$ retained in the solid phase as a function of the pyrolysis temperature for the different fuel samples after pyrolysis for $30 \mathrm{~min}$.

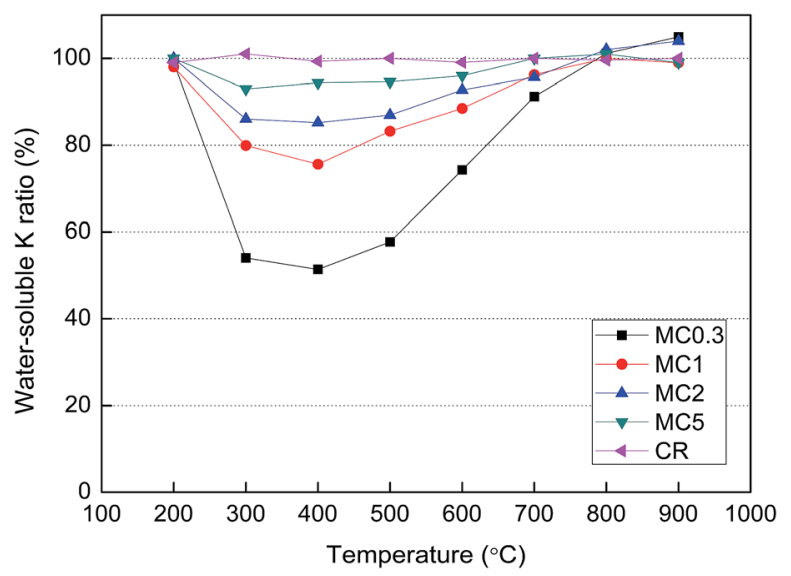

Fig. 3 Water-soluble $K$ to total $K$ ratio of the solid residues obtained after pyrolysis of the samples for $30 \mathrm{~min}$.

cellulose but the later do not. The different $\mathrm{K}$ retention behavior of the KCl-loaded cellulose samples and $\mathrm{CR}$ revealed that the organic matter in cellulose has an impact on the $\mathrm{K}$ transformation during pyrolysis.

Fig. 3 shows the ratio of water-soluble $\mathrm{K}$ to total $\mathrm{K}$ in the solid residues obtained after pyrolysis for $30 \mathrm{~min}$. The ratios remained below $96 \%$ for the MC0.3, MC1, MC2, and MC5

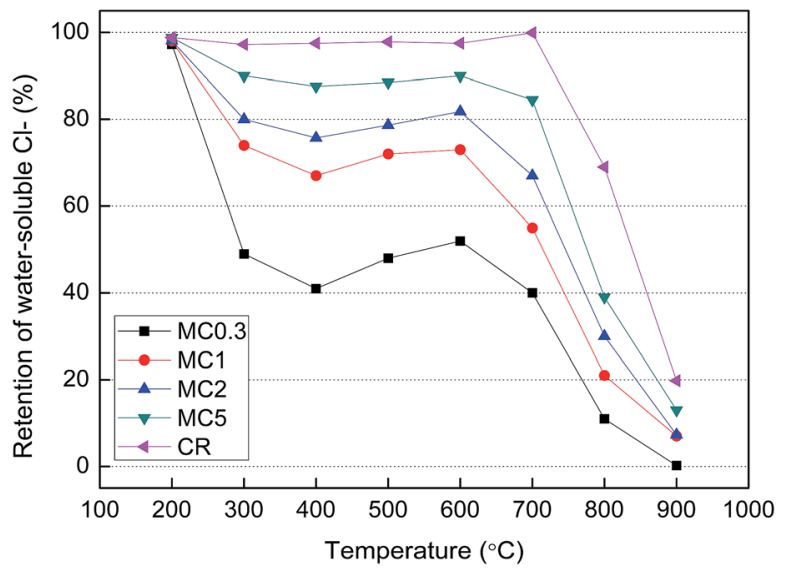

Fig. 4 Water-soluble $\mathrm{Cl}^{-}$retention of the solid residues obtained after pyrolysis of the different fuel samples for $30 \mathrm{~min}$.

samples after pyrolysis at $300-600{ }^{\circ} \mathrm{C}$, indicating that waterinsoluble $\mathrm{K}$ was formed in the solid residues at these temperatures. The ratios reached a minimum at $400{ }^{\circ} \mathrm{C}$. It can be estimated that about $52,27,19$, and $8 \%$ of the total $\mathrm{K}$ in the original MC0.3, MC1, MC2, and MC5 samples became waterinsoluble after pyrolysis at $400{ }^{\circ} \mathrm{C}$, respectively. Additionally, as shown in Fig. 3, the water-soluble $\mathrm{K}$ to total $\mathrm{K}$ ratio of the solid residue obtained after pyrolysis of CR remained nearly unchanged in the entire range of temperature studied herein $\left(200-900{ }^{\circ} \mathrm{C}\right)$.

The retention of water-soluble $\mathrm{Cl}^{-}$after pyrolysis of the MC0.3, MC1, MC2, MC5, and CR samples for $30 \mathrm{~min}$ was calculated using the following equation:

$$
\beta=\frac{m_{\mathrm{r}} c_{\mathrm{wsCl}, \mathrm{r}}}{m_{0} c_{\mathrm{wsCl}, 0}} \times 100 \%
$$

where $c_{\mathrm{wsCl}, 0}$ and $c_{\mathrm{wsCl}, \mathrm{r}}$ represent the concentrations of watersoluble $\mathrm{Cl}^{-}$in the original samples and in the solid residues after pyrolysis, respectively. As shown in Fig. 4, the amount of water-soluble $\mathrm{Cl}^{-}$retained for the MC0.3, MC1, MC2, and MC5 samples decreased with increased pyrolysis temperature and then reached a valley at $400{ }^{\circ} \mathrm{C}$, followed by a sharp drop from $600{ }^{\circ} \mathrm{C}$. On the other hand, the amount of water-soluble $\mathrm{Cl}^{-}$ retained by $\mathrm{CR}$ remained nearly unchanged for temperatures of 200-700 ${ }^{\circ} \mathrm{C}$ and decreased thereafter.

Fig. 5 represents the amount of $\mathrm{CO}_{3}{ }^{2-}$ of the solid residues obtained after pyrolysis of the samples for $30 \mathrm{~min}$. Since the eluent used during IC was a $\mathrm{NaOH}$ solution, the concentrations of $\mathrm{CO}_{3}{ }^{2-}$ directly obtained by this technique actually corresponded to the sum of the concentrations of $\mathrm{HCO}_{3}{ }^{-}$and $\mathrm{CO}_{3}{ }^{2-}$ in the detected water solution. As $\mathrm{KHCO}_{3}$ decomposes to form $\mathrm{K}_{2} \mathrm{CO}_{3}$ at temperatures above $200{ }^{\circ} \mathrm{C},{ }^{18}$ no $\mathrm{KHCO}_{3}$ was found in the solid residues. Instead, the only matter present was $\mathrm{K}_{2} \mathrm{CO}_{3}$ and therefore the concentrations of $\mathrm{CO}_{3}{ }^{2-}$ obtained from IC analysis were representative of the actual $\mathrm{CO}_{3}{ }^{2-}$ concentrations in the solid residues.

These results shown in Fig. 5 indicated that a certain amount of $\mathrm{CO}_{3}{ }^{2-}$ was generated during pyrolysis of MC0.3, MC1, MC2, and MC5 at temperatures higher than $600{ }^{\circ} \mathrm{C}$. The amount of 


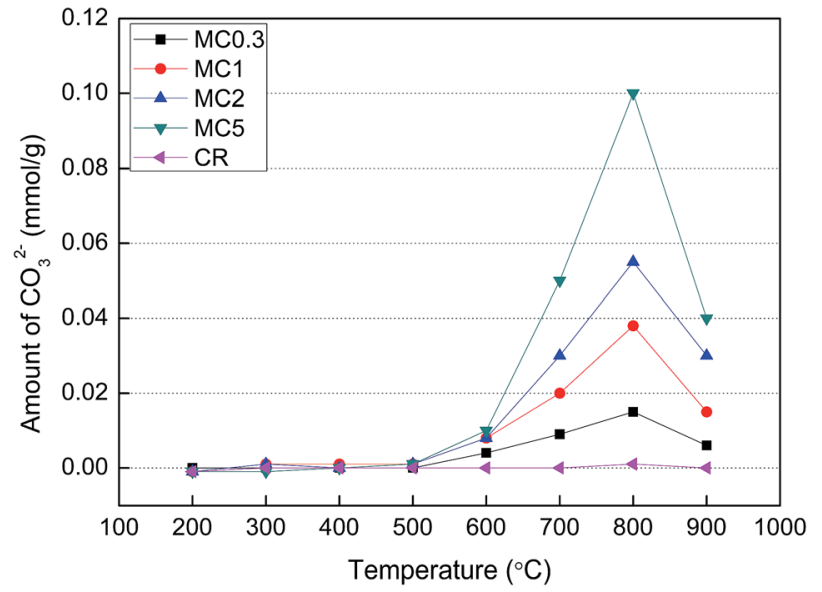

Fig. 5 Amount of $\mathrm{CO}_{3}{ }^{2-}$ for the solid residues obtained after pyrolysis of the samples for $30 \mathrm{~min}$.

$\mathrm{CO}_{3}{ }^{2-}$ in these samples reached a maximum at $800{ }^{\circ} \mathrm{C}$. In addition, the amount of $\mathrm{CO}_{3}{ }^{2-}$ increased with the increased content of $\mathrm{K}$ in the $\mathrm{KCl}$-loaded cellulose samples. In the case of the $\mathrm{CR}$ sample, no $\mathrm{CO}_{3}{ }^{2-}$ was found within the entire temperature range of the present study $\left(200-900{ }^{\circ} \mathrm{C}\right)$. These results indicated that the generation of $\mathrm{CO}_{3}{ }^{2-}$ was likely related to the organics in the cellulose. The generation pathway of $\mathrm{CO}_{3}{ }^{2-}$ during pyrolysis of the cellulose samples was discussed in Section 4.2.

\subsection{Influence of the residence time and the atmosphere}

Table 5 shows the retention of $\mathrm{K}$ and $\mathrm{Cl}^{-}$, the water-soluble $\mathrm{K}$ to total $\mathrm{K}$ ratio, and the amount of $\mathrm{CO}_{3}{ }^{2-}$ data for the MC2 sample after thermal conversion at different residence times and atmospheres. These four parameters remained nearly unchanged while increasing the residence time from 30 to $60 \mathrm{~min}$ after pyrolysis at $400{ }^{\circ} \mathrm{C}$. On the other hand, after pyrolysis at $800{ }^{\circ} \mathrm{C}$, the retention of $\mathrm{K}$ and water-soluble $\mathrm{Cl}^{-}$decreased with the increase of the residence time whereas the water-soluble $\mathrm{K}$ to total $\mathrm{K}$ ratio and the amount of $\mathrm{CO}_{3}{ }^{2-}$ remained constant.

As shown in Table 5, those four parameters remained nearly unchanged while the atmosphere changed from inert to oxidizing at $400{ }^{\circ} \mathrm{C}$. The retention of $\mathrm{K}$ and water-soluble $\mathrm{Cl}^{-}$ values under an oxidizing atmosphere were lower than those obtained under an inert atmosphere at $800{ }^{\circ} \mathrm{C}$. The amount of $\mathrm{CO}_{3}{ }^{2-}$ under an oxidizing atmosphere was larger as compared to that obtained under an inert atmosphere at $800{ }^{\circ} \mathrm{C}(0.070$ vs. $\left.0.055 \mathrm{mmol} \mathrm{g}^{-1}\right)$.

\section{Discussion}

In the present work, the water-soluble $\mathrm{K}$ mainly includes $\mathrm{KCl}$ and $\mathrm{K}_{2} \mathrm{CO}_{3}$ while the water-insoluble $\mathrm{K}$ mainly includes organic $\mathrm{K}$ and char $\mathrm{K}$ (i.e., $\mathrm{K}$ strongly bound to the char matrix). ${ }^{22,27}$ As $\mathrm{K}$ is the only inorganic cation, water-soluble $\mathrm{Cl}^{-}$and $\mathrm{CO}_{3}{ }^{2-}$ can be assumed to be in the forms of $\mathrm{KCl}$ and $\mathrm{K}_{2} \mathrm{CO}_{3}$ in the obtained solid residues. ${ }^{27,28}$ Therefore, the main chemical forms of $\mathrm{K}$ found herein can be classified into four kinds: (1) $\mathrm{KCl},(2)$ $\mathrm{K}_{2} \mathrm{CO}_{3}$, (3) water-insoluble $\mathrm{K}$, and (4) $\mathrm{K}$ released into the gas phase.

The results of the CR sample in Table 4 and Fig. 2-5 showed that the $\mathrm{K}$ in the solid residues obtained after pyrolysis at 200$900{ }^{\circ} \mathrm{C}$ remained in the form of $\mathrm{KCl}$, and no water-insoluble $\mathrm{K}$ or $\mathrm{K}_{2} \mathrm{CO}_{3}$ were generated. These results indicated that, during the pyrolysis of the CR sample, only $\mathrm{KCl}$ evaporation occurred.

The $\mathrm{K}$ distribution in the solid residues obtained after pyrolysis of the MC2 sample (representative of the KCl-loaded cellulose samples) for 30 min was illustrated in Fig. 6 based on the data in Table 4 and Fig. 2-5. The number of moles of water-soluble $\mathrm{Cl}^{-}$and $\mathrm{CO}_{3}{ }^{2-}$ were equal to those of $\mathrm{K}$ in the form of $\mathrm{KCl}$ and $\mathrm{K}_{2} \mathrm{CO}_{3}$ in the obtained solid residue, respectively. The amount of $\mathrm{K}$ released was equal to the initial amount of $\mathrm{K}$ in the samples minus the amount of $\mathrm{K}$ retained. With the aim to perform a $\mathrm{K}$ balance, the differences between the initial $\mathrm{K}$ content in the samples and the sum of the amounts of the above four K chemical forms were calculated for all the samples and symbolized as K(DV). All the samples showed relatively low $\mathrm{K}(\mathrm{DV})$ values, thereby indicating that the four chemical forms considered herein accounted for almost all the chemical forms of $\mathrm{K}$ present during the pyrolysis treatment. Also, the low K(DV) values revealed that the errors were maintained within an acceptable range.

The initial amount of $\mathrm{K}$ in the MC2 sample was $0.513 \mathrm{mmol} \mathrm{g}^{-1}$ and all of it was in the form of $\mathrm{KCl}$, as revealed by the results of the original samples shown in Table 4. As shown in Fig. 6, during the pyrolysis of $\mathrm{MC} 2$, $\mathrm{K}$ element was transformed into $\mathrm{KCl}, \mathrm{K}_{2} \mathrm{CO}_{3}$, water-insoluble $\mathrm{K}$, and released $\mathrm{K}$ as a function of temperature. The temperature can be divided into two regions: low temperature $\left(200-600{ }^{\circ} \mathrm{C}\right)$ and high temperature $\left(700-900{ }^{\circ} \mathrm{C}\right)$ regions.

\subsection{K transformation at low temperatures}

The results shown in Fig. 6 indicated that the transformation of $\mathrm{K}$ from $\mathrm{KCl}$ to water-insoluble $\mathrm{K}$ during the cellulose samples pyrolysis took place at $300-600{ }^{\circ} \mathrm{C}$, but this transformation was not observed for the CR sample. Thus, the transformation of $\mathrm{K}$

Table 5 Effect of the experimental conditions after MC2 thermal conversion at different residence times and under different atmospheres

\begin{tabular}{|c|c|c|c|c|c|c|}
\hline Experimental conditions $^{a}$ & P-400-30 & P-800-30 & P-400-60 & P-800-60 & C-400-30 & C- $800-30$ \\
\hline Retention of K (\%) & 95.1 & 47.8 & 95.0 & 35.1 & 94.7 & 33.7 \\
\hline Water-soluble K (\%) & 85.2 & 102.0 & 85.1 & 101.2 & 90.3 & 100.1 \\
\hline Retention of water-soluble $\mathrm{Cl}^{-}(\%)$ & 76.8 & 30.4 & 76.6 & 15.6 & 78.7 & 10.1 \\
\hline Amount of $\mathrm{CO}_{3}^{2-}\left(\mathrm{mmol} \mathrm{g}^{-1}\right)$ & 0 & 0.055 & 0 & 0.056 & 0 & 0.070 \\
\hline
\end{tabular}

${ }^{a} \mathrm{P}$ is pyrolysis; 30 or 60 indicates the residence time in $\mathrm{min}$; $\mathrm{C}$ is combustion. 


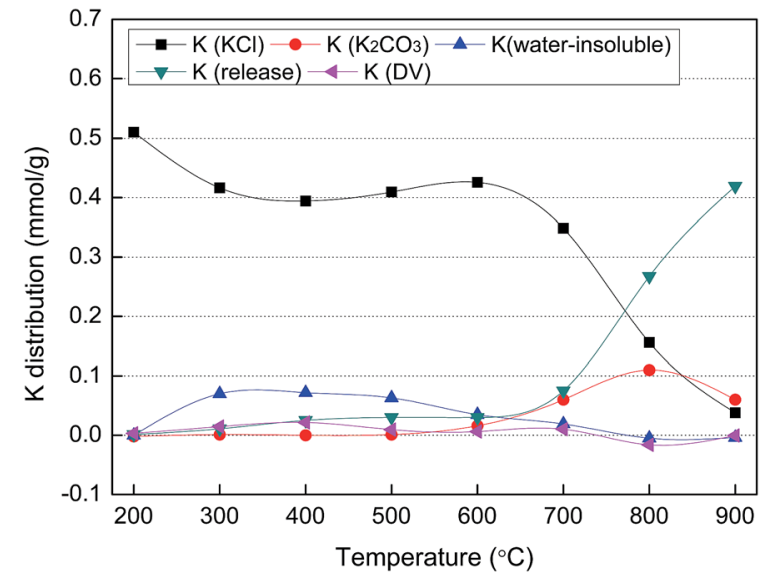

Fig. 6 Distribution of $\mathrm{K}$ after the pyrolysis of MC2 for $30 \mathrm{~min}$ as a function of temperature.

in the form of $\mathrm{KCl}$ into water-insoluble $\mathrm{K}$ is likely to be occurred through reaction (1) in which $\mathrm{K}$ atom in $\mathrm{KCl}$ replaces $\mathrm{H}$ atom in the active functional groups (e.g., carboxylic or phenolic groups) which are produced from pyrolysis of organic matter in cellu$\operatorname{los}^{29}$ and at the same time water-insoluble $\mathrm{K}$ is produced. As shown in Table 5 , the effect of the residence time on the $\mathrm{K}$ transformation behavior was negligible when pyrolysis was carried out at $400^{\circ} \mathrm{C}$. Since the process of cellulose pyrolysis was completed at $30 \mathrm{~min}$, no more active functional groups would be available to react with $\mathrm{KCl}$ at longer residence times.

The net solid yield ratio (after eliminating the water-soluble $\mathrm{K}$ and $\mathrm{Cl}^{-}$in the solid samples) was calculated as follows:

$$
\chi^{\prime}=\frac{m_{\mathrm{r}}\left(1-c_{\mathrm{wsK}, \mathrm{r}}-c_{\mathrm{wsCl}, \mathrm{r}}\right)}{m_{0}\left(1-c_{\mathrm{wsK}, 0}-c_{\mathrm{wsCl}, 0}\right)} \times 100 \%
$$

where $c_{\mathrm{wsK}, 0}$ and $c_{\mathrm{wsK}, \mathrm{r}}$ are the concentration of the water-soluble $\mathrm{K}$ in the original samples and in the solid residues, respectively. The amount of $\mathrm{KCl}$ that reacted with the functional groups at $300-600{ }^{\circ} \mathrm{C}$ was considered as the difference between the initial amount of $\mathrm{KCl}$ before pyrolysis and the amount of $\mathrm{KCl}$ in the solid residues obtained after pyrolysis. Fig. 7 shows the net solid yield ratio and the amount of the reacted $\mathrm{KCl}$ as a function of the $\mathrm{K}$ content in the cellulose samples during pyrolysis at 300 and $400{ }^{\circ} \mathrm{C}$. The solid yield ratio decreased with the $\mathrm{K}$ content increasing from 0 to $0.3 \mathrm{wt} \%$ during pyrolysis at $300{ }^{\circ} \mathrm{C}$. These results can be explained by the catalytic pyrolysis of cellulose by $\mathrm{KCl}$, which leads to an early pyrolysis process and low solid yields at $300{ }^{\circ} \mathrm{C} \cdot{ }^{30,31}$ During pyrolysis at $400{ }^{\circ} \mathrm{C}$, the solid yield ratio increased as the $\mathrm{K}$ content increasing from 0 to $0.3 \mathrm{wt} \%$. As shown in Fig. 7(1), the solid yield ratio hardly changed at $\mathrm{K}$ contents higher than $1 \mathrm{wt} \%$, thereby indicating that this amount of $\mathrm{K}$ was the saturation level for the catalytic effect of $\mathrm{KCl}$ during cellulose pyrolysis. At $\mathrm{K}$ contents higher than $1 \mathrm{wt} \%$, the active functional groups produced during cellulose pyrolysis would be similar. At $\mathrm{K}$ contents higher than $1 \mathrm{wt} \%$, shown in Fig. 7(2), the amount of reacted $\mathrm{KCl}$ increased with the increase of $\mathrm{K}$ content in the samples. These results indicated a secondary reactions between the released $\mathrm{HCl}$ and water-insoluble $\mathrm{K}$

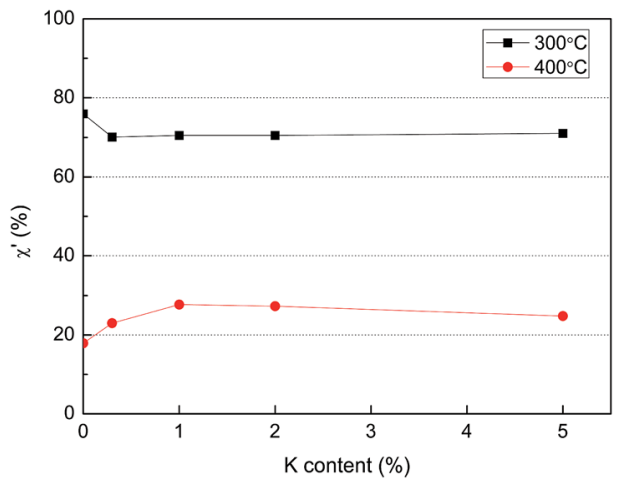

(1)

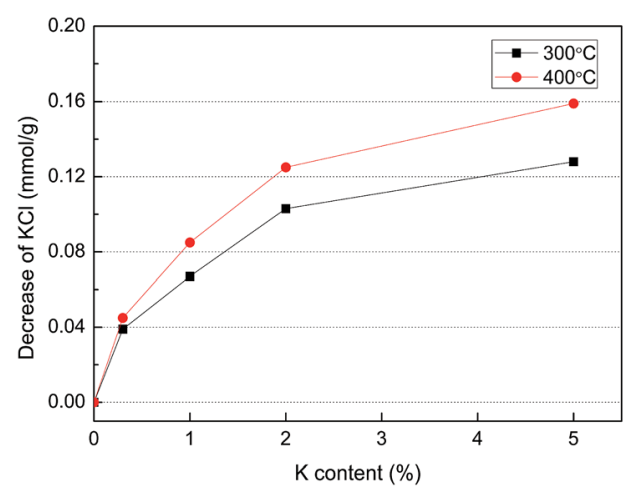

(2)

Fig. 7 Solid yield ratio (1) and amount of $\mathrm{KCl}$ reacted (2) during pyrolysis of $\mathrm{KCl}$-loaded cellulose samples at 300 and $400^{\circ} \mathrm{C}$.

occurred which induced re-condensation of $\mathrm{K}$ and $\mathrm{Cl}$ in the char. According to the above discussion, the reaction transforming $\mathrm{KCl}$ into water-insoluble $\mathrm{K}$ was governed by both the availability of active functional groups produced during cellulose pyrolysis and the amount of KCl.

\subsection{K transformation at high temperatures}

As shown in Fig. 6, during the pyrolysis of the MC2 sample at $600{ }^{\circ} \mathrm{C}$, the amount of $\mathrm{K}_{2} \mathrm{CO}_{3}$ increased with the decrease of water-insoluble $\mathrm{K}$. This tendency was more pronounced at 700 and $800{ }^{\circ} \mathrm{C}$. The results indicated that the water-insoluble $\mathrm{K}$ may be transformed into $\mathrm{K}_{2} \mathrm{CO}_{3}$ as the temperature increased. The amount of $\mathrm{K}$ in the form of $\mathrm{KCl}$ and $\mathrm{K}_{2} \mathrm{CO}_{3}$ at $800{ }^{\circ} \mathrm{C}$ was $0.16 \mathrm{mmol} \mathrm{g}^{-1}$ and $0.11 \mathrm{mmol} \mathrm{g}^{-1}$, respectively, which indicated that part of the initial $\mathrm{K}$ (in the form of $\mathrm{KCl}$ ) in the MC2 fuel was converted to $\mathrm{K}_{2} \mathrm{CO}_{3}$ during pyrolysis. The relative amount of $\mathrm{K}$ element in form of $\mathrm{KCl}$ converted to $\mathrm{K}_{2} \mathrm{CO}_{3}$ in the $\mathrm{MC0.3}$, MC1, MC2, MC5 fuel samples during pyrolysis at $800{ }^{\circ} \mathrm{C}$ (as compared to the initial $\mathrm{K}$ element amount in the fuels) was estimated as $39 \%, 29 \%, 21 \%$, and $16 \%$, respectively.

Based on our results, a possible mechanism of $\mathrm{K}_{2} \mathrm{CO}_{3}$ generation was proposed. First, $\mathrm{KCl}$ reacts with the organic functional groups (e.g., carboxylic or phenolic groups) which are produced from pyrolysis of organic matter in cellulose to form water-insoluble K. At temperature exceeding $600{ }^{\circ} \mathrm{C}$, water- 
insoluble $\mathrm{K}$ subsequently decomposes to form $\mathrm{K}_{2} \mathrm{CO}_{3}$. According to the data from Table 5, the oxidizing atmosphere was found to favor the generation of $\mathrm{K}_{2} \mathrm{CO}_{3}$ at $800{ }^{\circ} \mathrm{C}$. It is known that water-insoluble $\mathrm{K}$ can be decomposed either into potassium atoms and oxygen in gas phase or into $\mathrm{K}_{2} \mathrm{CO}_{3}{ }^{11}$ The oxidizing atmosphere can inhibit the release of oxygen and enhance the formation of $\mathrm{K}_{2} \mathrm{CO}_{3}$.

Fig. 2 demonstrated that significant amounts of $\mathrm{K}$ were released at temperatures higher than 600 and $700{ }^{\circ} \mathrm{C}$ during pyrolysis of the KCl-loaded cellulose samples and the CR sample, respectively. The $\mathrm{K}$ in the $\mathrm{KCl}$-loaded cellulose samples was mainly released via $\mathrm{KCl}$ vaporization, $\mathrm{K}_{2} \mathrm{CO}_{3}$ decomposition or water-insoluble $\mathrm{K}$ decomposition above $700{ }^{\circ} \mathrm{C}$. The relatively lower temperature of $\mathrm{K}$ release for $\mathrm{KCl}$-loaded cellulose samples can be explained in terms of the $\mathrm{K}_{2} \mathrm{CO}_{3}$ generated during pyrolysis decreasing the melting point of the $\mathrm{K}$ salts. ${ }^{32}$ In contrast, no $\mathrm{K}_{2} \mathrm{CO}_{3}$ was found for the $\mathrm{CR}$ sample at $700{ }^{\circ} \mathrm{C}$. In addition, longer residence time enhanced $\mathrm{K}$ release during pyrolysis of the MC2 sample at $800{ }^{\circ} \mathrm{C}$ (Table 5) because $\mathrm{KCl}$ was continuously vaporized. When compared with an inert atmosphere at $800{ }^{\circ} \mathrm{C}$, the higher amounts of $\mathrm{K}$ release under an oxidizing atmosphere (Table 5) were likely caused by the reduction of the diffusion resistance of the char matrix.

\section{Conclusions}

The transformation behavior of $\mathrm{K}$ involving the conversion of water-insoluble $\mathrm{K}$ and $\mathrm{K}_{2} \mathrm{CO}_{3}$ during pyrolysis of biomass was quantitatively investigated by using KCl-loaded cellulose as fuels in the present work. The results of the microscopic morphology indicated that the micro-distribution status and particle sizes of the inorganic matter particles in the $\mathrm{KCl}$ loaded cellulose samples were similar to those of natural rice straw. Four different chemical forms of $\mathrm{K}$ were studied: (1) $\mathrm{KCl}$, (2) $\mathrm{K}_{2} \mathrm{CO}_{3}$, (3) water-insoluble $\mathrm{K}$, and (4) $\mathrm{K}$ released into the gas phase. The results indicated that, during the pyrolysis of the CR sample, only $\mathrm{KCl}$ evaporation occurred. During pyrolysis of the KCl-loaded cellulose samples, a certain amount of water-insoluble $\mathrm{K}$ was formed at temperatures above $300{ }^{\circ} \mathrm{C}$. The reaction transforming $\mathrm{KCl}$ into waterinsoluble $\mathrm{K}$ was found to be governed by both the availability of active functional groups produced during cellulose pyrolysis and the amount of KCl. The water-insoluble $\mathrm{K}$ decomposed to form $\mathrm{K}_{2} \mathrm{CO}_{3}$ above $600{ }^{\circ} \mathrm{C}$. Furthermore, the results indicated that this newly generated $\mathrm{K}_{2} \mathrm{CO}_{3}$ promoted $\mathrm{K}$ release into the gas phase. We suggest that the transformation of $\mathrm{KCl}$ into water-insoluble $\mathrm{K}$ and $\mathrm{K}_{2} \mathrm{CO}_{3}$ should be emphasized for the further research of $\mathrm{K}$ transformation during the thermal conversion of biomass.

\section{Acknowledgements}

The authors wish to gratefully acknowledge the financial support received from the National Natural Science Foundation of China (51661125012).

\section{References}

1 R. Saidur, E. A. Abdelaziz, A. Demirbas, M. S. Hossain and S. Mekhilef, Renewable Sustainable Energy Rev., 2011, 15, 2262-2289.

2 A. A. Khan, W. de Jong, P. J. Jansens and H. Spliethoff, Fuel Process. Technol., 2009, 90, 21-50.

3 P. A. Jensen, F. J. Frandsen, K. Dam-Johansen and B. Sander, Energy Fuels, 2000, 14, 1280-1285.

4 L. Li, C. Yu, F. Huang, J. Bai, M. Fang and Z. Luo, Energy Fuels, 2012, 26, 6008-6014.

5 M. W. Szczerba, D. T. Britto and H. J. Kronzucker, J. Plant Physiol., 2009, 166, 447-466.

6 R. A. Leigh and R. Jones, New Phytol., 1984, 97, 1-13.

7 S. B. Liaw and H. Wu, Ind. Eng. Chem. Res., 2013, 52, 42804289.

8 J. N. Knudsen, P. A. Jensen and K. Dam-Johansen, Energy Fuels, 2004, 18, 1385-1399.

9 C. Chen, C. Yu, H. Zhang, X. Zhai and Z. Luo, Fuel, 2016, 167, 180-187.

10 S. C. van Lith, P. A. Jensen, F. J. Frandsen and P. Glarborg, Energy Fuels, 2008, 22, 1598-1609.

11 J. M. Johansen, J. G. Jakobsen, F. J. Frandsen and P. Glarborg, Energy Fuels, 2011, 25, 4961-4971.

12 S. B. Saleh, J. P. Flensborg, T. K. Shoulaifar, Z. Sárossy, B. B. Hansen, H. Egsgaard, N. DeMartini, P. A. Jensen, P. Glarborg and K. Dam-Johansen, Energy Fuels, 2014, 28, 3738-3746.

13 H. Wu, M. S. Bashir, P. A. Jensen, B. Sander and P. Glarborg, Fuel, 2013, 113, 632-643.

14 J. M. Johansen, M. Aho, K. Paakkinen, R. Taipale, H. Egsgaard, J. G. Jakobsen, F. J. Frandsen and P. Glarborg, Proc. Combust. Inst., 2013, 34, 2363-2372.

15 Z. Zhang, Q. Song, Q. Yao and R. Yang, Energy Fuels, 2012, 26, 1892-1899.

16 P. A. Tchoffor, K. O. Davidsson and H. Thunman, Energy Fuels, 2013, 27, 7510-7520.

17 S. C. van Lith, V. Alonso-Ramírez, P. A. Jensen, F. J. Frandsen and P. Glarborg, Energy Fuels, 2006, 20, 964-978.

18 H. Zhao, Q. Song, X. Wu and Q. Yao, Energy Fuels, 2015, 29, 6404-6411.

19 J. R. Dodson, A. J. Hunt, V. L. Budarin, A. S. Matharu and J. H. Clark, RSC Adv., 2011, 1, 523-530.

20 H. Fatehi, Y. He, Z. Wang, Z. S. Li, X. S. Bai, M. Alden and K. F. Cen, Proc. Combust. Inst., 2015, 35, 2389-2396.

21 T. Sorvajärvi, N. DeMartini, J. Rossi and J. Toivonen, Appl. Spectrosc., 2014, 68, 179-184.

22 H. Chen, X. Chen, Z. Qiao and H. Liu, Fuel, 2016, 167, 31-39. 23 D. Keown, G. Favas, J. Hayashi and C. Li, Bioresour. Technol., 2005, 96, 1570-1577.

24 J. Long, H. Song, X. Jun, S. Sheng, S. Lun-shi, X. Kai and Y. Yao, Bioresour. Technol., 2012, 116, 278-284.

25 C. Du, L. Liu and P. Qiu, RSC Adv., 2017, 7, 10397-10406.

26 M. U. Rahim, X. Gao and H. Wu, Proc. Combust. Inst., 2015, 35, 2891-2896. 
27 H. Watanabe, K. Shimomura and K. Okazaki, Proc. Combust. Inst., 2015, 35, 2423-2430.

28 A. Kosminski, D. P. Ross and J. B. Agnew, Fuel Process. Technol., 2006, 87, 943-952.

29 A. Anca-Couce, Prog. Energy Combust. Sci., 2016, 53, 41-79.
30 A. Jensen, K. Dam-Johansen, M. A. Wójtowicz and M. A. Serio, Energy Fuels, 1998, 12, 929-938.

31 T. Khazraie Shoulaifar, N. DeMartini, O. Karlstr and M. Hupa, Fuel, 2016, 165, 544-552.

32 FactSage salt database, http:/www.crct.polymtl.ca/FACT/ documentation/. 